\title{
EFFECTS OF BOVINE LUTEINIZING HORMONE AND HUMAN CHORIONIC GONADOTROPHIN ON THE BOVINE CORPUS LUTEUM IN VIVO
}

\author{
D. W. SCHOMBERG, S. P. COUDERT AND R. V. SHORT \\ Department of Veterinary Clinical Studies and \\ A.R.C. Unit of Reproductive Physiology and Biochemistry, University of Cambridge
}

(Received 23rd Fanuary 1967)

\begin{abstract}
Summary. The steroidogenic effects of bovine luteinizing hormone $(\mathrm{LH})$ and human chorionic gonadotrophin (HCG) in vivo were investigated by measuring the concentration of progesterone in peripheral plasma as an index of luteal secretory activity. The gonadotrophins were injected intravenously on Days 5, 10, 15 and 20 of the oestrous cycle, and serial samples of peripheral blood obtained before and after the injections. The steroidogenic response to $\mathrm{LH}$ or HCG was variable. Statistically significant increases in plasma progesterone levels were produced in five out of ten experiments; the magnitude of this increase was less than $100 \%$ in three cases and the duration of stimulation was less than $3 \mathrm{hr}$ in four cases. The life-span of the corpus luteum was prolonged and new ovulations were induced by the gonadotrophins.
\end{abstract}

\section{INTRODUCTION}

The corpus luteum differs from almost all other endocrine glands in that it is a transitory structure with a short but variable life-span. Theoretically, it could be influenced by at least two different types of trophic stimuli, the one increasing its secretory activity, and the other prolonging its life-span.

In the cow, there is abundant evidence from in-vitro incubation and perfusion studies to show that luteinizing hormone $(\mathrm{LH})$ or human chorionic gonadotrophin (HCG) increases the rate of progesterone synthesis by luteal tissue (Savard, Marsh \& Rice, 1965; Hall \& Koritz, 1965; Armstrong \& Black, 1966; Hansel, 1966; Romanoff, 1966). In vivo, both LH and HCG can prolong the life of the corpus luteum (Wiltbank, Rothlisberger \& Zimmerman, 1961; Donaldson \& Hansel, 1965). Thus, both types of luteotrophic activity seem to be vested in the one hormone, LH. On the other hand, prolactin, which can prolong the life of the corpus luteum in the rat and mouse, cannot prolong the life of the bovine corpus luteum (Smith, McShan \& Casida, 1957; Armstrong \& Hansel, 1959); however, it may have some effect on its secretion in in-vitro perfusions (Romanoff, 1966).

Peripheral blood progesterone levels can be used to give some indication of changes in the secretory activity of the bovine corpus luteum, since the levels 
fall abruptly after enucleation of the corpus luteum (McCracken, 1963a), and during the oestrous cycle they rise and fall with the development and regression of the corpus luteum (McGracken, 1963b; Plotka, Erb, Callahan \& Gomes, 1966). We have therefore attempted to measure changes in the peripheral blood progesterone levels following LH or HCG administration.

\section{MATERIAL AND METHODS}

\section{Reproductive status}

Three Ayrshire cows were used throughout these experiments; Nos. 1 and 2 were non-pregnant and non-lactating and No. 3 was non-pregnant, but lactating. Ovarian morphology was determined by rectal palpation throughout the control and treatment cycles, particular attention being paid to the day of treatment and the following day. Cows No. 1 and 2 were slaughtered at the end of the treatment cycle; the corpora lutea were immediately dissected from the ovaries, weighed, a portion removed for histological examination and the remainder frozen until assayed for progesterone.

\section{Injections of gonadotrophins}

The gonadotrophins were administered on Days 5, 10,15 and 20 of the treatment cycle. In the HCG experiments, two pre-injection control samples were taken, the first immediately after insertion of an indwelling venous catheter $(-1 \mathrm{hr})$ and the second $(0 \mathrm{hr})$ immediately before gonadotrophin injection; six hourly post-injection samples were collected. The HCG (5000 i.u., Lutormone, Burroughs Wellcome \& Co.), dissolved in $10 \mathrm{ml}$ saline, was administered as a single intravenous injection.

Bovine LH (30 mg NIH-LH-B3) was administered to cow No. 3 by two methods: (1) as a continuous intravenous drip infusion in $500 \mathrm{ml}$ of saline lasting $50 \mathrm{~min}$ on Day 10, and (2) as a single intravenous injection in $10 \mathrm{ml}$ saline on Day 15. In these trials, three pre-injection control and eight post-injection treatment samples were collected at half-hourly intervals.

\section{Catheterization and blood collection}

An indwelling polyethylene catheter was introduced into the jugular vein using the Seldinger method (1953). An adaptor with a removable rubber septum was attached to the end of the catheter and held in place by a suture through the skin. Jugular vein blood, $50 \mathrm{ml}$ samples, was collected into a heparinized syringe at timed intervals; between collections the catheter was filled with heparinized saline. After collection, the blood was immediately centrifuged at room temperature for $1 \mathrm{hr}$ and the plasma placed in the deep freeze until assay.

\section{Extraction procedures}

An internal standard of $7-{ }^{3} \mathrm{H}$ progesterone $(0.008 \mu \mathrm{g} ; 0.03 \mu \mathrm{c})$ was added to the plasma to correct for extraction losses. The plasma samples (25 to $30 \mathrm{ml}$ ) were extracted according to the method of Short (1958), which involved the addition of alkali, ether extraction and evaporation of the solvent to dryness. The petroleum ether $170 \%$ methanol partition step was omitted. 
The corpora lutea $(0.3$ to $0.5 \mathrm{~g}$ of tissue) were processed according to the above procedure after homogenization with $2.5 \% \mathrm{NaOH}$.

Following paper chromatography in the ligroin $/ 80 \%$ methanol system, the progesterone zone was eluted into a flask containing $0.48 \mu \mathrm{g} 20 \beta$-acetoxypregn-4-en-3-one. The eluate was taken to dryness, re-dissolved in methanol and one-tenth of this was counted in a Packard Tri-Carb (model 3003) liquid scintillation counter with a tritium counting efficiency of $46 \%$. The liquid scintillation medium consisted of $4.0 \mathrm{~g}$ PPO (2,5-diphenyloxazole) and $0.1 \mathrm{~g}$ POPOP (1,4 bis-2(5-phenyloxazolyl)) dissolved in 1 litre of toluene.

\section{Quantitative analysis}

The remainder of the eluate was then transferred to a small tube, evaporated to dryness and redissolved in $10 \mu \mathrm{l}$ of acetone; approximately 5 to $6 \mu \mathrm{l}$ of this was taken up in a micro-syringe and injected into an F \& M Model 400 gas chromatograph containing a 4-ft glass column packed with $3.8 \%$ SE-30 on Diaport S. The oven temperature was maintained at $220^{\circ} \mathrm{C}$. The steroids were then quantitated by cutting out and weighing the peaks traced on the chart recorder and solving the equation:

$\mu \mathrm{g}$ progesterone in eluate $=$

$$
\frac{(\mu \mathrm{g} 20 \beta \text {-acetoxypregn-4-en-3-one) (weight of progesterone peak) }}{\text { weight of } 20 \beta \text {-acetoxypregn-4-en-3-one peak }}
$$

This result was then corrected for extraction losses. Appropriate standards of progesterone and 20 $\beta$-acetoxypregn-4-en-3-one were run with each set of unknowns.

In order to check the validity of this technique for quantitating the transfer to the gas chromatograph and to establish the linearity of detector response over the range of progesterone expected in the plasma, varying amounts of progesterone $(0.1$ to $1.1 \mu \mathrm{g})$ were added to a standard amount of $20 \beta$-acetoxypregn4-en-3-one $(0.48 \mu \mathrm{g})$ and aliquots injected as described above. The ratios were then plotted against the mass of progesterone. The coefficient of variation of thirty-three such determinations was $\pm 6 \cdot 7 \%$. The lower limit of sensitivity was $0.02 \mu$ g progesterone.

\section{Control cycles}

\section{RESULTS}

It seemed desirable to investigate the variability of the levels of peripheral plasma progesterone on selected days of the oestrous cycle in normally cycling, untreated cows. In order to establish the degree of statistical variability associated with an individual progesterone determination, four blood samples were collected by means of indwelling catheters at hourly intervals from cows No. 1 and 2 on Days 5, 10, 15 and 20 of a control oestrous cycle. A sample mean and variance were assigned to each set of four samples. Bartlett's method (Snedecor, 1953) was used to test for homogeneity of variance (unequal numbers) between days of the cycle and among cows. Examination of the data representing the control cycles of cows No. 1 and 2 revealed no statistically significant differences in the variance of samples taken at different stages of the 
cycle of the same cow or between the two cows (Table 1) with the exception of the set collected from cow No. 1 on Day 15. Since the variance of this set was significantly different from the pooled variance estimate, fiducial limits could not be applied. Excluding this group, the $95 \%$ fiducial limits for means ranging from $0 \cdot 10$ to $0.76 \mu \mathrm{g}$ progesterone $/ 100 \mathrm{ml}$ plasma were $\pm 0 \cdot 13 \mu \mathrm{g} / 100 \mathrm{ml}$ plasma.

\section{Treatment cycles}

Cow No. 1. The plasma progesterone concentrations of cow No. 1 are shown in Text-fig. 1. Treatment with HGG caused a significant increase in the blood progesterone concentrations on Day 5; in contrast, treatment on Days 10, 15 and 20 had no effect. Effects of gonadotrophin treatment were tested for statistical significance with Student's $t$-test (Snedecor, 1953) using the pooled

TABLE 1

VARIATION OF PROGESTERONE CONCENTRATION $(\mu \mathrm{g} / 100 \mathrm{ml}$ PLASMA) IN SAMPLES COLLEGTED HOURLY OVER 4 HOURS ON SELECTED DAYS OF THE OESTROUS GYCLE FROM TWO COWS

\begin{tabular}{|c|c|c|c|c|}
\hline \multirow{2}{*}{ Cow } & \multicolumn{4}{|c|}{ Days since oestrus } \\
\hline & 5 & 10 & 15 & 20 \\
\hline $\begin{array}{c}\text { No. } 1 \\
0 \mathrm{hr} \\
1 \mathrm{hr} \\
2 \mathrm{hr} \\
3 \mathrm{hr}\end{array}$ & $\begin{array}{l}0 \cdot 23 \\
0 \cdot 17 \\
0 \cdot 16 \\
0 \cdot 15\end{array}$ & $\begin{array}{r}0.41 \\
0.47 \\
0.37 \\
*\end{array}$ & $\begin{array}{l}1.52 \\
0.59 \\
0.71 \\
0.76\end{array}$ & $\begin{array}{r}0 \cdot 20 \\
0 \cdot 24 \\
0 \cdot 17 \\
\quad *\end{array}$ \\
\hline $\begin{array}{l}\text { Mean } \\
\text { Variance }\end{array}$ & $\begin{array}{l}0 \cdot 18 \\
0.0010\end{array}$ & $\begin{array}{l}0.41 \\
0.0017\end{array}$ & $\begin{array}{l}1 \cdot 16 \\
0 \cdot 1340\end{array}$ & $\begin{array}{l}0.20 \\
0.0008\end{array}$ \\
\hline $\begin{array}{c}\text { No. } 2 \\
0 \mathrm{hr} \\
1 \mathrm{hr} \\
2 \mathrm{hr} \\
3 \mathrm{hr}\end{array}$ & $\begin{array}{l}0.46 \\
0.38 \\
0.49 \\
0.38\end{array}$ & $\begin{array}{r}0.56 \\
0.67 \\
0.42 \\
*\end{array}$ & $\begin{array}{l}0.71 \\
0 \cdot 77 \\
0.74 \\
0.80\end{array}$ & $\begin{array}{l}0 \cdot 18 \\
0.04 \\
0.05 \\
0 \cdot 13\end{array}$ \\
\hline $\begin{array}{l}\text { Mean } \\
\text { Variance }\end{array}$ & $\begin{array}{l}0.43 \\
0.0024\end{array}$ & $\begin{array}{l}0 \cdot 55 \\
0 \cdot 0105\end{array}$ & $\begin{array}{l}0.76 \\
0.0011\end{array}$ & $\begin{array}{l}0.10 \\
0.0034\end{array}$ \\
\hline
\end{tabular}

* Sample not obtained.

variance estimate obtained from control cycle data. The treatment cycle followed the control cycle.

Rectal examinations showed that by Day 15 the corpus luteum had regressed in size. Rectal examination on Day 16 indicated that a new ovulation had occurred in response to the gonadotrophin injection of Day 15. The cow failed to return to oestrus at the expected time, and was killed on Day 23. The ovaries contained two heavily luteinized follicles, the corpus luteum that had been formed by the Day 15 HCG injection $(2.5 \mathrm{~g})$, and a corpus albicans $(0.5 \mathrm{~g})$ which probably represented the original corpus luteum formed on Day 1 of the cycle. Histological examination of the corpus albicans showed it to be devoid of functional tissue whereas the induced corpus luteum appeared normal.

No steroid determinations were carried out on the tissues from this animal. The low plasma progesterone concentrations found on Day $15(0.2 \mu \mathrm{g} / 100 \mathrm{ml}$ 
plasma) also suggest that the original corpus luteum had begun to regress some time between Days 10 and 15.

Cow No. 2. The plasma progesterone levels of cow No. 2 are shown in Textfig. 2. In contrast to cow No. 1, HCG did not produce a significant increase in plasma progesterone on Day 5. Significant responses, however, were produced on Days 10, 15 and 20.

As in the first experiment, a fresh ovulation was induced by the injection of

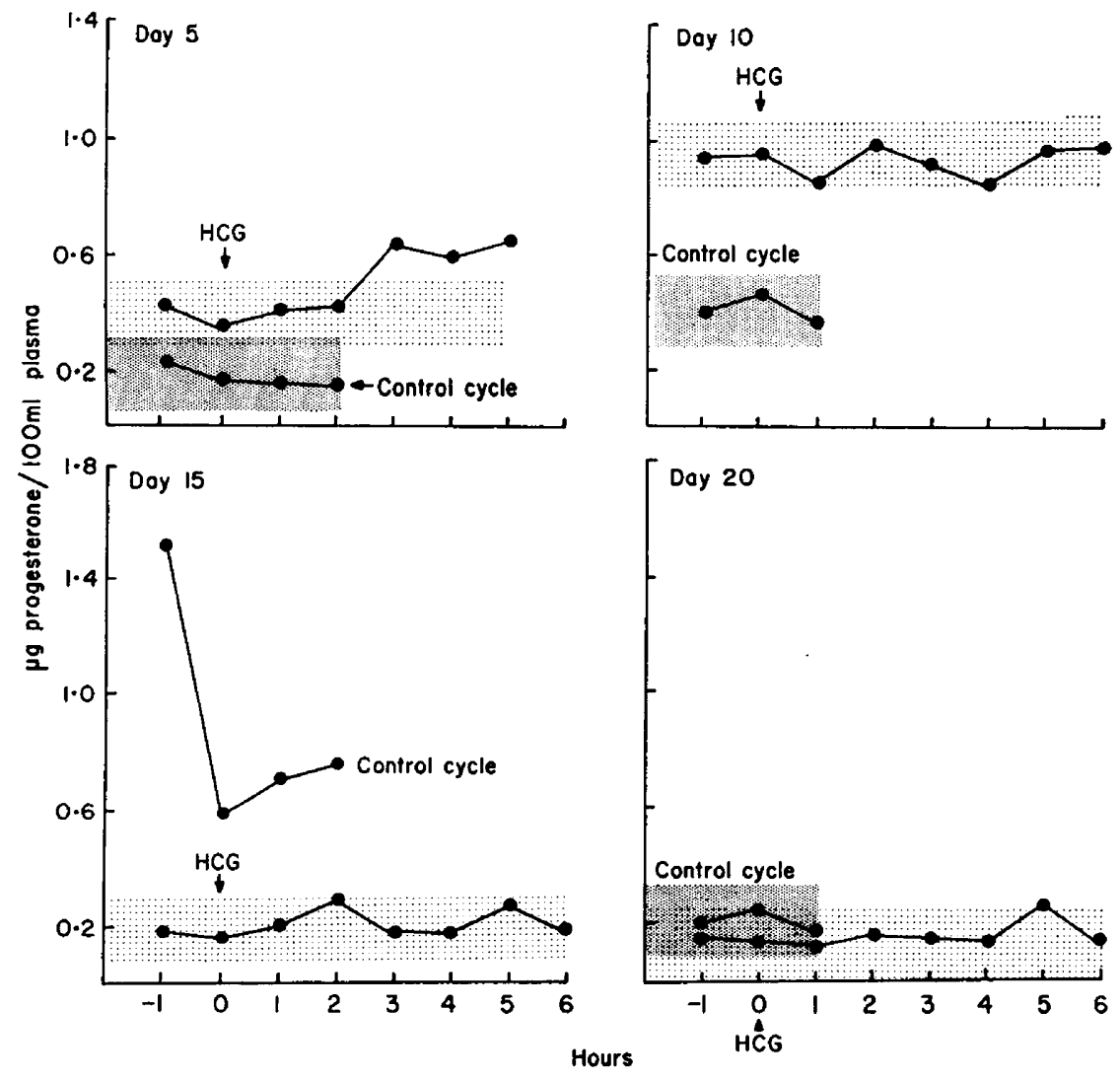

TEXT-FIG. 1. Cow No. 1 : the effect of 5000 i.u. HCG on the concentration of progesterone in peripheral plasma on different days of the oestrous cycle. Fine stippling, 95\% fiducial limits of control cycle means; coarse stippling, $95 \%$ fiducial limits of control sample means (treatment cycle).

HCG on Day 15, but, in contrast to cow No. 1, the original corpus luteum was also maintained. The cow was killed on Day 21 , and the ovaries contained the two corpora lutea and two large Graafian follicles. The weights and progesterone concentrations of both the original corpus luteum and the induced corpus luteum were within the normal range $(7.2 \mathrm{~g}, 34.0 \mu \mathrm{g} / \mathrm{g} ; 3.4 \mathrm{~g}, 24.4 \mu \mathrm{g} / \mathrm{g})$, and the two glands were histologically indistinguishable from one another.

The pre-treatment progesterone concentration of $0.6 \mu \mathrm{g} / 100 \mathrm{ml}$ plasma observed on Day 20 (Text-fig. 2) exceeded levels previously noted on Day 20 
of the normal cycle, and was probably due to the presence of the two functional corpora lutea.

Cow No. 3. The effects of bovine LH on circulating plasma progesterone are shown in Text-fig. 3. Contrary to expectations, a significant response was noted
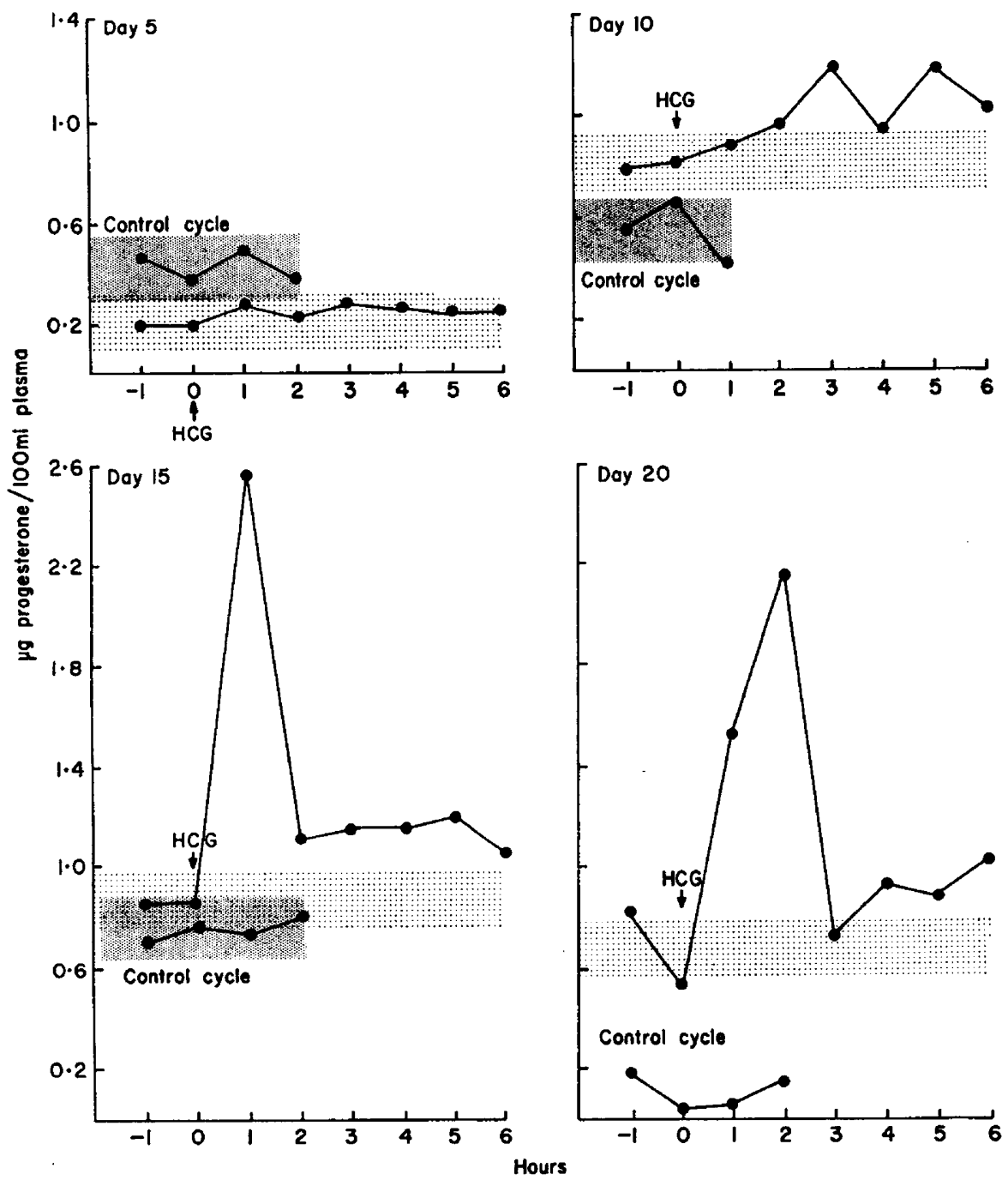

TexT-Fig. 2. Cow No. 2: the effect of 5000 i.u. HGG on the concentration of progesterone in peripheral plasma on different days of the oestrous cycle. Fine stippling, $95 \%$ fiducial limits of control cycle means; coarse stippling, $95 \%$ fiducial limits of control sample means (treatment cycle).

after a single intravenous injection of LH on Day 15 whereas the LH infusion on Day 10 had little or no effect. The extensive variation between the Day 10 control samples is disturbing; there was no obvious technical explanation for this.

The injection of LH on Day 15 induced a new ovulation, and the original 
corpus luteum of the cycle was also maintained. The cow returned to oestrus on Day 27.

In summary, LH or HGG treatment produced statistically significant increases in plasma progesterone levels in only five out of ten experiments. The magnitude of this increase was less than $100 \%$ in three cases; the duration of stimulation was less than $3 \mathrm{hr}$ in four cases. HCG appeared to bring about premature regression of the corpus luteum in one animal (No. 1) whereas a single injection of LH on Day 15 prolonged the cycle to 27 days in another (No. 3). Intravenous

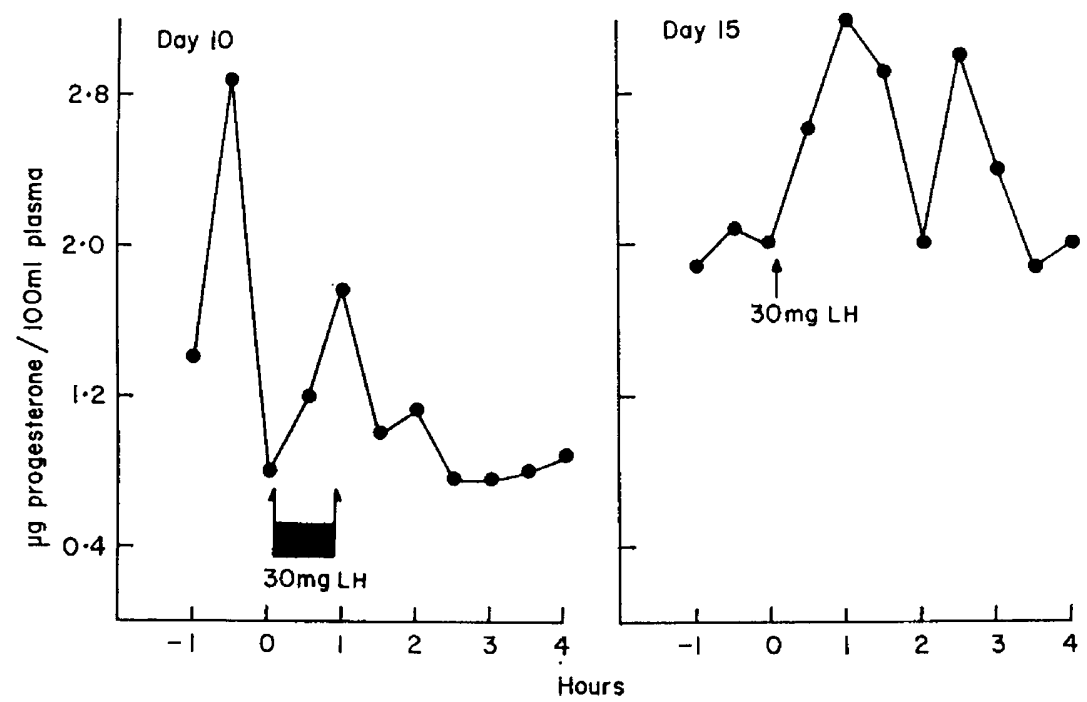

Text-Fig. 3. Cow No. 3. Comparison of the effects of bovine LH $(30 \mathrm{mg})$ on the concentration of progesterone in peripheral plasma when administered as a continuous infusion $(50 \mathrm{~min})$ or as a single injection.

gonadotrophin administration on Day 15 induced a new ovulation in all the animals.

\section{DISCUSSION}

Any attempt to measure changes in progesterone secretion by the corpus luteum from a study of the peripheral blood progesterone levels obviously introduces a number of uncontrolled variables. It is possible that there could be changes in the metabolic clearance rate of the hormone as a result of gonadotrophin treatment. Changes in adrenal progesterone secretion may also complicate the results, since the bovine adrenals can secrete large amounts of progesterone $(1.5 \mathrm{mg} / \mathrm{hr}$ ), at least under condition of operative stress (Short, 1960). The results of this study must, therefore, be viewed in the light of these limitations. On theoretical grounds, changes in the peripheral blood level of a hormone with a high metabolic clearance rate, such as progesterone, should accurately and rapidly reflect changes in the production rate of the hormone (Tait \& Burstein, 1964).

In vitro, the bovine corpus luteum responds to bovine LH or HCG with a two- to 
ten-fold increase in steroid synthesis (Savard et al., 1965). The in-vivo responses that we have obtained are clearly much less pronounced than this; in half the experiments we failed to observe any response at all, and Short (1967) failed to produce any alteration in the peripheral blood progesterone level in two cows after injections of 15,000 i.u. HCG. It is interesting that in their initial studies, Savard et al. (1965) likewise failed to elicit a steroidogenic response in a number of corpora lutea. Also, Armstrong \& Black (1966) reported that although the in-vitro rate of progesterone secretion/g of luteal tissue is constant during the first 14 days of the cycle, younger glands responded less to added gonadotrophin.

It seems that the bovine corpus luteum in vivo responds to HCG in a very different manner to the testis. In the bull, an intravenous injection of a comparable amount of HCG results in a rapid (within $17 \mathrm{~min}$ ) and sustained (for at least $75 \mathrm{~min}$ ) ten- to fifteen-fold increase in the testosterone secretion rate; the concentration of testosterone in testicular tissue is also increased considerably ( 1.5 to 8 -fold) in response to gonadotrophin treatment (Lindner, 1961). In the cow, on the other hand, HCG given after oxytocin treatment sometimes increases the size of the corpus luteum, but it has a rather variable effect on the progesterone concentration in luteal tissue (Hansel, 1966).

Whilst there is conclusive evidence that LH or HCG can prolong the life of the corpus luteum in the cow, our studies suggest that the effect on progesterone secretion is variable. From a biological standpoint, it may be more important for a luteotrophin to prolong the functional life of the corpus luteum, rather than to increase its secretory activity. In this connection, it is worth noting that neither the progesterone concentration in luteal tissue nor in peripheral blood of the cow is increased if the corpus luteum of the cycle is converted to a corpus luteum of pregnancy (Gomes \& Erb, 1965).

One would like to be able to conclude that luteinizing hormone is luteotrophic in the cow, acting by prolonging the life, and sometimes increasing the secretory activity, of the corpus luteum. However, other pituitary hormones as well as uterine factors might also influence the bovine corpus luteum in vivo. We do not know whether LH is the only luteotrophic hormone and we do not know whether it acts directly on the corpus luteum or indirectly, e.g. by altering the ovarian secretion of other steroids which, in turn, might modify the uterine luteolytic effect.

\section{ACKNOWLEDGMENTS}

This work was carried out during the tenure of a National Institutes of Health Postdoctoral fellowship (No. 1-F2-HD-24, 930-01) awarded to D.W.S. One of us (S.P.C.) acknowledges an Anglo-French clinical Research Grant, awarded jointly by the Medical Research Council and the Institut National de la Santé de la Recherche Médicale. The bovine LH was a gift of the Endocrine Study Section of the National Institutes of Health. We are also grateful to Dr T. Mann, Dr R. E. Erb and Dr R. M. Moor for reading the manuscript and making helpful suggestions.

\section{REFERENGES}

ARmstrong, D. T. \& BLAck, D. L. (1966) Influence of luteinizing hormone on corpus luteum metabolism and progesterone biosynthesis throughout the bovine estrous cycle. Endocrinology, 78, 937. 
Armstrong, D. T. \& Hansel, W. (1959) Alteration of the bovine estrous cycle with oxytocin. $\mathcal{F}$. Dairy Sci. 42, 533.

Donaldson, L. E. \& Hansel, W. (1965) Prolongation of life span of the bovine corpus luteum by single injections of bovine luteinising hormone. 7. Dairy Sci. 48, 903.

Gomes, W. R. \& ERB, R. E. (1965) Progesterone in bovine reproduction: A review. 7. Dairy Sci. 48, 314.

Hall, P. F. \& Koritz, S. B. (1965) Influence of interstitial cell-stimulating hormone on the conversion of cholesterol to progesterone by bovine corpus luteum. Biochemistry, 4, 1037.

Hansel, W. (1966) Luteotrophic and luteolytic mechanisms in bovine corpora lutea. 7. Reprod. Fert. Suppl. 1, 33.

LINDNER, H. R. (1961) Androgens and related compounds in the spermatic vein blood of domestic animals. I. Neutral steroids secreted by the bull testis. F. Endocr. 23, 159.

MaCracken, J. A. (1963a) Plasma progesterone concentration after removal of the corpus luteum in the cow. Nature, Lond. 198, 507.

MaCracken, J. A. (1963b) Distribution of progesterone in body fluids and tissues of the dairy cow. Thesis, University of Glasgow.

Plotka, E. D., ERb, R. E., Gallahan, C. J. \& Gomes, W. R. (1966) Levels of progesterone in peripheral blood plasma of the cycling cow. (Abstract). J. Dairy Sci. 49, 731.

Romanorf, E. B. (1966) Steroidogenesis in the perfused bovine ovary. F. Reprod. Fert. Suppl. 1, 88.

Savard, K., Marsh, J. M. \& Rice, B. F. (1965) Gonadotropins and ovarian steroidogenesis. Recent Prog. Horm. Res. 21, 285.

Seldinger, S. I. (1953) A catheter replacement of the needle in percutaneous arteriography. Acta radiol. 39, 368.

Short, R. V. (1958) Progesterone in blood. I. The chemical determination of progesterone in peripheral blood. F. Endocr. 16, 415.

Short, R. V. (1960) The secretion of sex hormones by the adrenal gland. Biochem. Soc. Symp. 18, 59.

SHORT, R. V. (1967) The luteotrophic control of the bovine corpus luteum. Colloque sur la Physiologie de la Reproduction chez les Mammifères. (In press.)

Smith, V. R., McShan, W. H. \& Casida, L. E. (1957) On maintenance of the corpora lutea of the bovine with lactogen. F. Dairy Sci. 40, 443.

Snedecor, G. W. (1953) Statistical methods, 4th edn. Iowa State College Press, Ames, Iowa.

TAIt, J. F. \& Burstein, S. (1964) In vivo studies of steroid dynamics in man. In: The Hormones, Vol. 5, p. 441. Eds. G. Pincus, K. V. Thimann \& E. B. Astwood. Academic Press, New York.

Wiltbank, J. N., Rothlisberger, J. A. \& Zimmerman, D. R. (1961) Effect of human chorionic gonadotrophin on maintenance of the corpus luteum and embryonic survival in the cow. $\mathcal{F}$. Anim. Sci. 20, 827. 